\title{
KAŽNJIVO PONAŠANJE SUDIONIKA U PROMETU UTEMELJENO NA PRETHODNOM ISKUSTVU KAŽNJAVANJA
}

Doc. dr. sc. Stjepan Gluščić*

\author{
UDK 343.346 \\ https://doi.org/10.30925/zpfsr.42.3.2 \\ Ur.: 9. lipnja 2021. \\ Pr.: 7. kolovoza 2021. \\ Izvorni znanstveni rad
}

\begin{abstract}
Sažetak
Rad se bavi ponašanjima koja najčešće dovode do počinjenja teških prometnih nesreća. Navedena ponašanja kategoriziraju se kao prekršaji. Uz analizu navedenih prekršaja u posljednjih deset godina u istraživačkom dijelu rada analiziraju se podatci prikupljeni provedenim istraživanjem javnoga mnijenja (2.072 ispitanika) o stanju sigurnosti u prometu, ponašanju i navikama samih sudionika. Cilj je istraživanja bio utvrditi postoji li razlika u kažnjivom ponašanju sudionika u prometu s obzirom na prethodno iskustvo u kažnjavanju te na temelju dobivenih rezultata odrediti mjere kojima bi se jačala sigurnost cestovnog prometa i smanjio broj prometnih nesreća (kaznenih djela i prekršaja).
\end{abstract}

Ključne riječi: prekršaji; sigurnost; cestovni promet; kažnjavanje.

\section{UVODNA POJAŠNJENJA}

Da bi se poštovali i prihvatili zahtjevi koje građanima upućuju pravne norme (a što se odnosi i na odluke utemeljene na njima), važno je osigurati njihovo javno prihvaćanje. To je posebice važno stoga što su pravne norme u pravilu određena ograničenja te upućuju zahtjeve za određenom vrstom ponašanja. To je temeljno stajalište preduvjet uspješnog ostvarivanja određenih politika koje u svojoj osnovi imaju sigurnost u cjelini ili pojedinom njezinu segmentu. Tako je i s prometom na cestama. Ovaj je segment društvenog života iznimno važan za funkcioniranje cjelokupne društvene zajednice. Poremećaji koji utječu na njegovo ugrožavanje temelje se većim dijelom na grubom nepoštovanju pravila koja ga normiraju. Ponajprije, i u ovome se radu referira na povrede pravnih pravila svrstanih u kategoriju prekršaja i kažnjavanja njihovih počinitelja kao načina kojima želimo utjecati na to da počinitelji u budućnosti ne čine takve prekršaje. Zakonodavac kažnjavanjem želi utjecati na ponašanje počinitelja, poslati mu, kroz izrečenu kaznu, poruku da to ponašanje nije prihvatljivo. ${ }^{1}$

* Dr. sc. Stjepan Gluščić, docent, Visoka policijska škola u Zagrebu; sgluscic@fkz.hr. ORCID: https://orcid.org/0000-0002-2243-2694.

1 Vidi: Igor Bojanić i Marin Mrčela, „Svrha kažnjavanja u kontekstu šeste novele Kaznenog 
U suvremenim teorijama kažnjavanja kao svrha kažnjavanja određuje se specijalna i opća (generalna) prevencija. Ne samo utjecaj na konkretnog počinitelja kroz specijalnu prevenciju, već i utjecaj na javnost radi sprječavanja počinjenja kažnjivih radnji bez osobnog iskustva kažnjavanja, ali utemeljenog na iskustvu nekoga drugog (opća prevencija). ${ }^{2}$ Iz navedene opće prevencije usklađenost ponašanja s pravnim propisima želi se osigurati i bez kažnjavanja i u tome je kontekstu važno pitanje: Zašto građani poštuju određena pravila i zašto poštuju pravne propise ${ }^{3}$ Pojedini teoretičari ističu da građani u pravilu poštuju određena pravila jer smatraju da se pravnim pravilima moraju i mogu zahtijevati određena ponašanja ili jer zahtijevano ponašanje odgovara i njihovu stavu i moralu. ${ }^{4}$

Motorizirani je cestovni promet iznimno važan za suvremeni način života i možemo ustvrditi da bez dostignutog stupnja razvoja i naš način života ne bi ni postajao. U njemu svakodnevno sudjeluje veliki broj osoba (kao sudionici i nužni korisnici) koje čine izrazito veliki broj prometnih prekršaja, tj. sudjeluju u velikom broju prometnih nesreća i čine određeni broj kaznenih djela.

Tablica 1. Prekršaji koje je evidentirala policija prema Zakonu o sigurnosti cestovnog prometa i evidentirana kaznena djela iz područja sigurnosti prometa na cestama ${ }^{5}$

\begin{tabular}{|c|c|c|}
\hline Godina & $\begin{array}{c}\text { Ukupan broj prekršaja prema } \\
\text { policijskim evidencijama iz } \\
\text { područja sigurnosti prometa }\end{array}$ & $\begin{array}{c}\text { Ukupan broj kaznenih } \\
\text { djela prema policijskim } \\
\text { evidencijama iz područja } \\
\text { sigurnosti prometa }\end{array}$ \\
\hline 2011. & 769.721 & 1751 \\
\hline 2012. & 731.239 & 1626 \\
\hline 2013. & 732.475 & 1557 \\
\hline 2014. & 798.596 & 1334 \\
\hline 2015. & 827.628 & 1471 \\
\hline 2016. & 826.576 & 1461 \\
\hline 2017. & 752.785 & 1489 \\
\hline 2018. & 722.095 & 1308 \\
\hline 2019. & 714.399 & 1180 \\
\hline 2020. & 696.540 & \\
\hline
\end{tabular}

zakona“, Hrvatski ljetopis za kazneno pravo i praksu 13, br. 2 (2006): 431-449, Petar Novoselec i Igor Bojanić. Opći dio kaznenog prava, četvrto izdanje (Zagreb: Pravni fakultet Sveučilišta u Zagrebu, 2013.), 367; Ana Garačić, Kazneni zakon u sudskoj praksi (Zagreb: Organizator, 2006.), 21.

2 Vidi: Bojanić i Mrčela, „Svrha kažnjavanja u kontekstu šeste novele Kaznenog zakona“, 431449.

3 Vidi: Željko Horvatić i Leo Cvitanović, Politika suzbijanja kriminaliteta (Zagreb: Ministarstvo unutarnjih poslova, 1999.), 93; Snježana Maloić, „Suvremeni pristupi kažnjavanju kao determinante kvalitete života u obitelji, susjedstvu i zajednici - nove perspektive suzbijanja kriminala“, Kriminologija i socijalna integracija, 21, br. 2 82013): 31-44.

4 Vidi: Tom R. Tyler, Why Poople obey the Law (New Haven and London: Yale University Press, 1990.), 26.

5 Podatci dostupni na: https://mup.gov.hr. 
Tablica 2. Evidentirane prometne nesreće sa stradalima i poginulim osobama iz područja sigurnosti cestovnog prometa $^{6}$

\begin{tabular}{|c|c|c|c|c|c|c|}
\hline Godina & $\begin{array}{c}\text { Prometne } \\
\text { nesreće }\end{array}$ & $\begin{array}{c}\text { Prometne } \\
\text { nesreće s } \\
\text { nastradalim } \\
\text { osobama } \\
\text { nesreća s } \\
\text { nastradalim } \\
\text { osobama u } \\
\text { ukupnom broju } \\
\%\end{array}$ & $\begin{array}{c}\text { Udio prometnih } \\
\text { Poginule } \\
\text { osobe }\end{array}$ & $\begin{array}{c}\text { Ozlijeđene } \\
\text { osobe }\end{array}$ & $\begin{array}{c}\text { Udio poginulih } \\
\text { osoba u nastradalim } \\
\text { osobama u } \\
\text { ukupnom broju } \\
\%\end{array}$ \\
\hline 2011. & 42.443 & 13.228 & 31,2 & 418 & 18.065 & 2,3 \\
\hline 2012. & 37.065 & 11.773 & 31,8 & 393 & 16.010 & 2,4 \\
\hline 2013. & 34.021 & 11.225 & 33 & 368 & 15.274 & 2,4 \\
\hline 2014. & 31.432 & 10.607 & 33,7 & 308 & 14.222 & 2,1 \\
\hline 2015. & 32.571 & 11.038 & 33,9 & 348 & 15.024 & 2,3 \\
\hline 2016. & 32.757 & 10.779 & 32,9 & 307 & 14.596 & 2,1 \\
\hline 2017. & 34.368 & 10.939 & 31,8 & 331 & 14.608 & 2,2 \\
\hline 2018. & 33.440 & 10.450 & 31,3 & 317 & 13.989 & 2,2 \\
\hline 2019. & 31.367 & 9.695 & 30,9 & 297 & 12.885 & 2,3 \\
\hline 2020. & 26.074 & 7.496 & 28,7 & 237 & 10.035 & 2,3 \\
\hline
\end{tabular}

Podatci navedeni u tablici 1. i 2. pokazuju jačanje sigurnosti u području cestovnog prometa. Navedeni zaključak temelji se na kontinuiranom padu ukupnog broja prometnih nesreća (osim za 2015.), počinjenih prekršaja i kaznenih djela te broju poginulih i povrijeđenih osoba, ali je još uvijek riječ o iznimno velikom broju promatranih pojava.

U cilju jačanja sigurnosti prometa na cestama izrađuju se različiti strateški dokumenti. Jedan je od njih i Nacionalni program sigurnosti cestovnog prometa Republike Hrvatske. ${ }^{7}$ Jedna je od njegovih zadaća strateški definirati ciljeve na području cestovnog prometa kao i metode i načine njihovih dostizanja. Kao dio istraživanja za izradu novoga Nacionalnog programa provedeno je i istraživanje o utjecaju raznih čimbenika na sigurnost cestovnog prometa.

U ovome radu analiziraju se rezultati provedenog istraživanja o razlozima zbog kojih pri sudjelovanju u prometu sudionici poštuju ili ne poštuju propise koji uređuju to ponašanje, s osvrtom na utjecaj prethodnoga kažnjavanja na navedeno ponašanje.

\section{METODOLOGIJA ISTRAŽIVANJA}

\subsection{Cilj istraživanja}

Cilj je provedenog istraživanja ispitati postoji li razlika u kažnjivom ponašanju sudionika u prometu (vozača, putnika u vozilu i pješaka) s obzirom na njihovo prethodno iskustvo kažnjavanja; odnosno utvrditi je li iskustvo kažnjavanja povezano

6 Podatci dostupni na: https://mup.gov.hr.

7 Osnovni podatci o Nacionalnom programu sigurnosti cestovnog programa dostupni su na:

https://npscp.info/. 
s kasnijim ponašanjem sudionika u prometu u smislu kršenja prometnih pravila.

\subsection{Uzorak}

Uzorak je ukupno obuhvatio 2.072 ispitanika starijih od 16 godina. Sudjelovanje ispitanika u istraživanju bilo je anonimno i dragovoljno. Uzorak je reprezentativan za Republiku Hrvatsku prema spolu, dobi i regijama, što znači da se rezultati ovoga istraživanja mogu primijeniti na ukupnu populaciju.

\subsection{Instrument}

Istraživanje javnoga mnijenja o stanju sigurnosti, ponašanju te navikama sudionika u cestovnom prometu provedeno je s pomoću posebno sastavljenog anketnog upitnika. Anketni je upitnik obuhvatio ukupno 35 pitanja ili tvrdnji, uz napomenu kako su određena pitanja zapravo skale koje se odnose na kažnjiva ponašanja sudionika $u$ prometu (vozača, putnika i pješaka). U istraživanju je korišten multimetodički pristup $\mathrm{i}$ to kombinacija telefonskog istraživanja (CATI - 40 \%) i online istraživanja (CAWI $-60 \%$ ). Terensko prikupljanje podataka (anketiranje) provodila je agencija KvakaUred za kreativnu analizu d.o.o.

\subsection{Način provođenja istraživanja}

Rad je dio projekta koji je financirao Nacionalni program sigurnosti prometa na cestama. U smislu generalnih etičkih načela u znanstvenim istraživanjima poštovana je anonimnost ispitanika u smislu da identifikacijski podatci nisu unošeni u anketne upitnike. Terensko prikupljanje podataka provedeno je u rujnu i listopadu 2019.

\subsection{Način obrade podataka}

Nakon prikupljenih podataka, podatci su uneseni u bazu podataka u statističkom računalnom programu SPSS, a po dovršenom unosu obavljena je logička kontrola. Za potrebe definiranih ciljeva istraživanja korištena je deskriptivna statistika, za testiranje normalnosti distribucije frekvencija varijabli korišten je Kolmogorov-Smirnovljev test; dok je za ispitivanje razlika između skupina sudionika u prometu s obzirom na njihovo iskustvo kažnjavanja, korišten Kruskal-Wallisov test kao neparametrijska metoda, uvažavajući činjenicu da je prethodnim analizama utvrđeno kako su sve testirane varijable nenormalno distribuirane.

\section{REZULTATI ISTRAŽIVANJA}

Ako se pogleda dob ispitanika obuhvaćena provedenim istraživanjem vidljivo je kako je relativno najviše ispitanika bilo u dobi od 55. do 64. godine, a potom relativno jednako ispitanika koji su bili u dobi od 35. do 44. godine; od 45. do 54. godine; odnosno onih starijih od 65 . godina $(13 \%)$. 


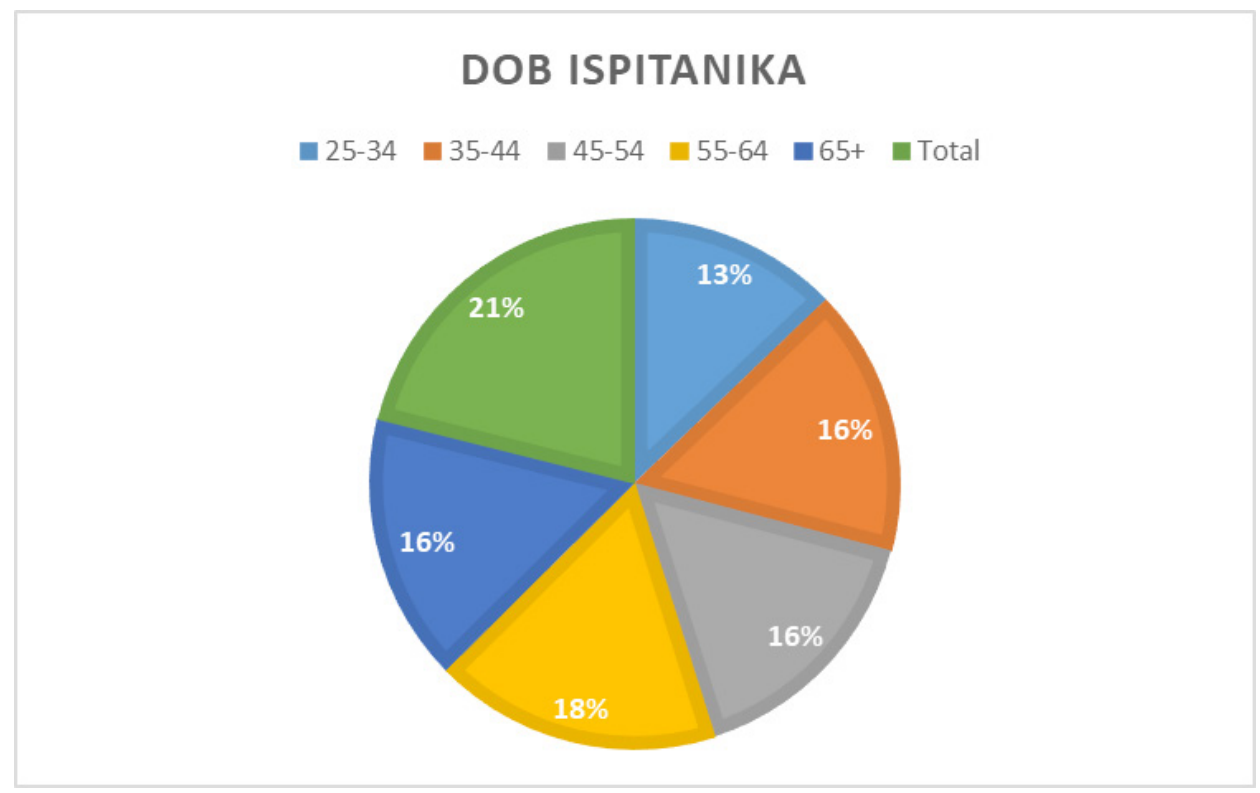

\section{Grafikon 1. Dob ispitanika}

Kada se područje Republike Hrvatske podijeli u šest regija (Slavonija ${ }^{8}$; Sjeverna Hrvatska ${ }^{9}$; Istra, Primorje, Gorski kotar ${ }^{10}$; Lika, Banovina i Kordun ${ }^{11}$; Zagreb ${ }^{12}$ i Dalmacija ${ }^{13}$ ), vidljivo je kako je zastupljen relativno najveći broj ispitanika iz Zagreba (26\%), potom iz Dalmacije (20\%), a nakon toga s relativno jednakim udjelima slijede Sjeverna Hrvatska i Slavonija (17 \%).

8 Slavonija: Požeško-slavonska, Brodsko-posavska, Osječko-baranjska i Vukovarsko-srijemska županija.

9 Sjeverna Hrvatska: Krapinsko-zagorska, Varaždinska, Koprivničko-križevačka, Bjelovarskobilogorska, Virovitičko-podravska i Međimurska županija.

10 Istra, Primorje i Gorski kotar: Primorsko-goranska i Istarska županija.

11 Lika, Kordun i Banovina: Sisačko-moslavačka, Karlovačka i Ličko-senjska županija.

12 Zagreb: Grad Zagreb i Zagrebačka županija.

13 Dalmacija: Zadarska, Šibensko-kninska, Splitsko-dalmatinska i Dubrovačko-neretvanska županija. 


\section{REGIJA}

\begin{tabular}{|c|c|}
\hline E Slavonija & - Lika, Banovina i Kordun \\
\hline - Sjeverna Hrvatska & - Zagreb \\
\hline
\end{tabular}

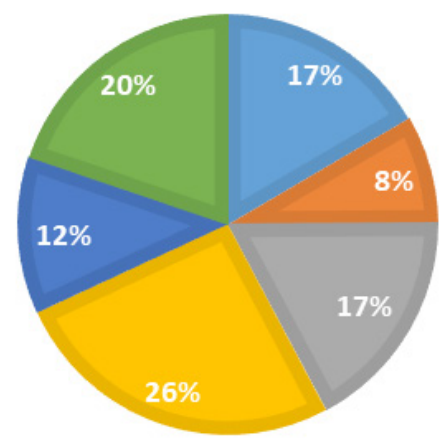

Grafikon 2. Zastupljenost ispitanika prema regijama

Iz grafikona 3 vidljivo je vozačko iskustvo ispitanika. Relativno najveći broj ispitanika imao je vozačko iskustvo dulje od 15 godina; dok je relativno najmanji broj u ukupnom uzorku otpao na one ispitanike čije je vozačko iskustvo bilo 12 mjeseci ili manje.

\section{Godine vozačkog iskustva}

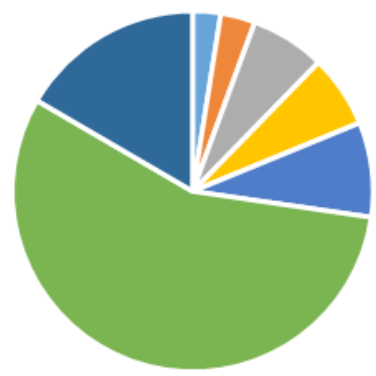

- 12 mjeseci i manje

n $13-24$ mjeseca

- 25 - 48 mjeseci (4 godine)

49- 8 godina

- 8 godina i 1 mjesec do 15 godina = Više od 15 godina

- Nema iskustva

Grafikon 3. Godine vozačkog iskustva ispitanika 
Najveći broj ispitanika koji su sudjelovali u provedenom istraživanju tijekom istraživanja bilo je zaposleno na pola radnog vremena ili na puno radno vrijeme (52 \%). Potom u ukupnom uzorku slijede ispitanici koji su bili u mirovini (28 \%).

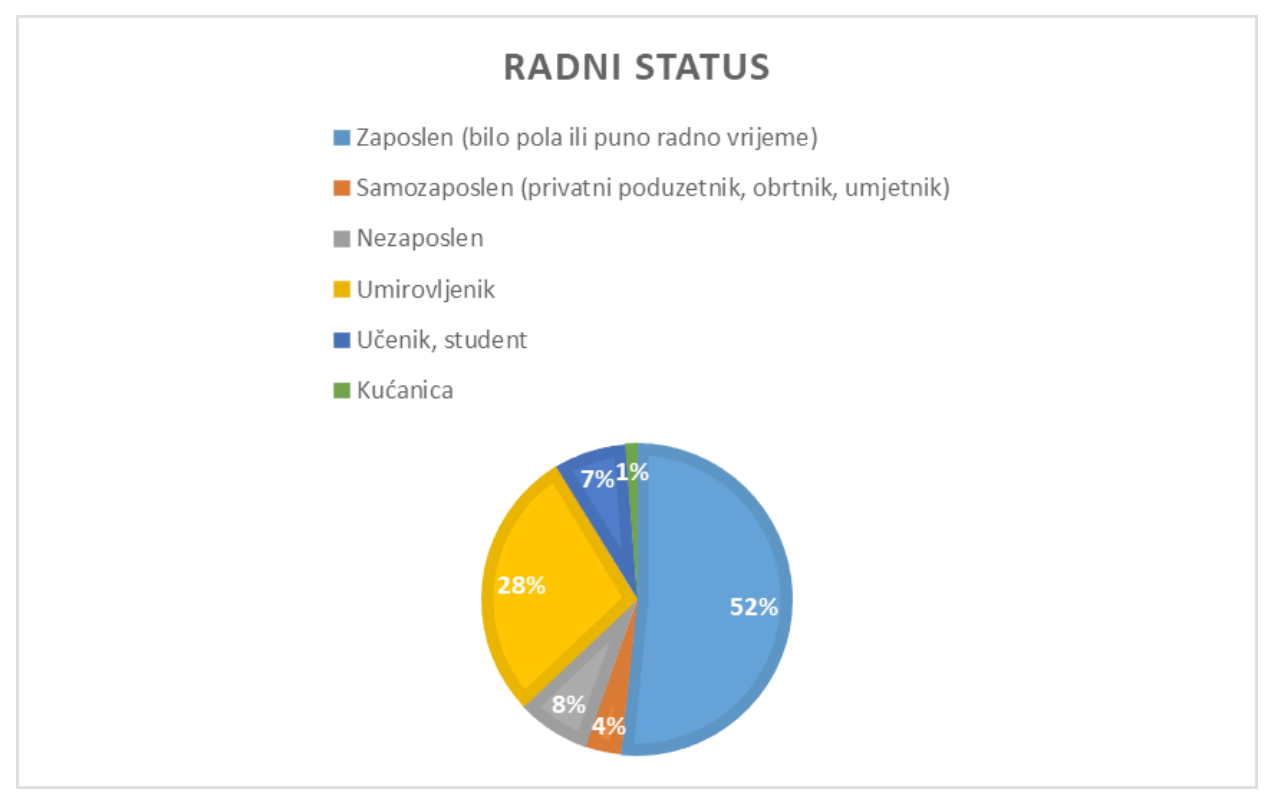

Grafikon 4. Radni status ispitanika

Mjesečna primanja ispitanika obuhvaćenih uzorkom istraživanja pokazala su kako ih najviše ima mjesečna primanja viša od 10.000 kuna. Nakon njih s podjednakim mjesečnim primanjima slijede ispitanici čija su mjesečna primanja bila od 4.001 kune do 6.000 kuna, od 6.001 kune do 8.000 kuna, odnosno oni čija su mjesečna primanja bila od 8.001 kune do 10.000 kuna. 


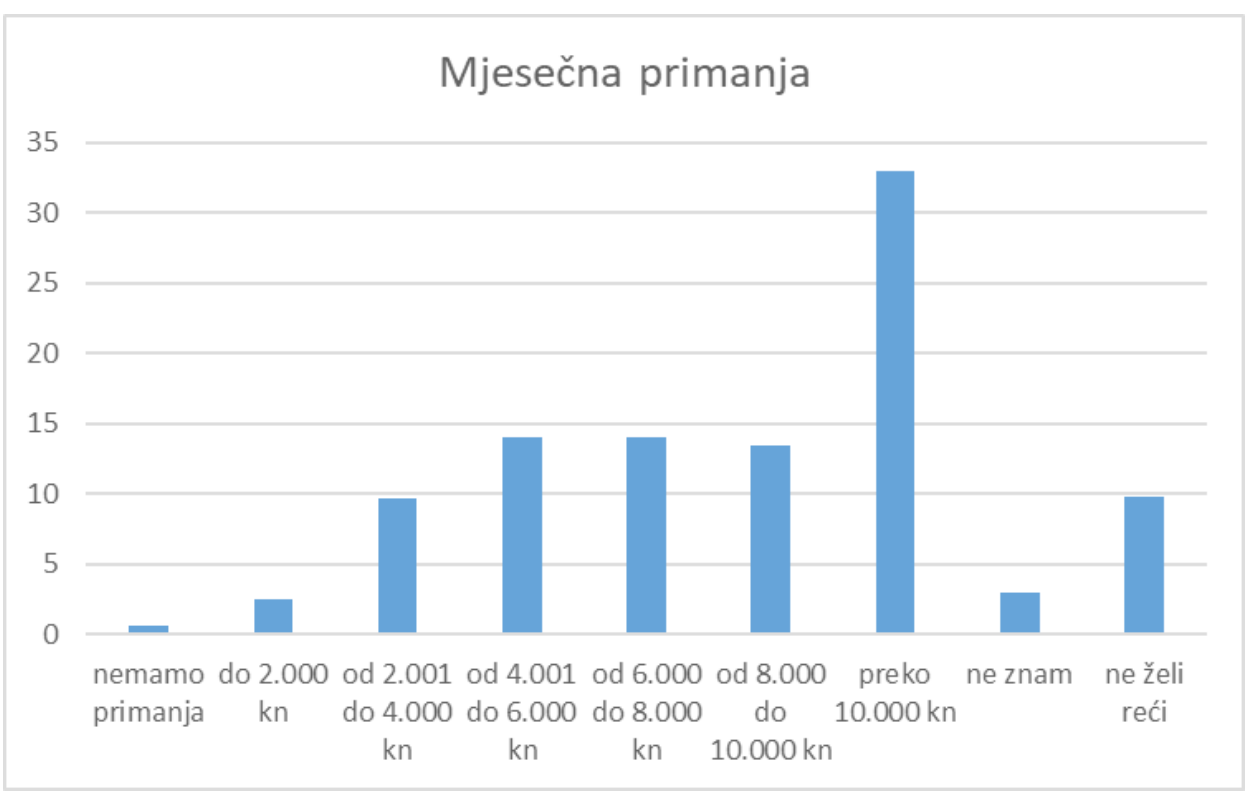

Grafikon 5. Mjesečna primanja ispitanika

Za ispitivanje razlika u kažnjivom ponašanju između skupina vozača s obzirom na njihovo iskustvo kažnjavanja u prometu najprije su izračunati osnovni statistički pokazatelji svih varijabli koje definiraju kažnjiva ponašanja vozača, putnika, biciklista i pješaka. U tablici 1. prikazani su osnovni statistički pokazatelji za sve varijable koje definiraju kršenje prometnih propisa (Q6.1 - Q6.14), kažnjiva ponašanja putnika i pješaka (Q9.1 - Q9.5) te kršenje prometnih propisa vozača i putnika (Q3, Q5). Sve ove varijable Likertova su tipa s pet kategorija odgovora i to: 1 - nikada, 2 - ponekad, 3 - često, 4 - uvijek i 9 - ne znam, ne mogu procijeniti. S obzirom na to su da sve ove varijable ordinalne, bilo je moguće izračunati aritmetičke sredine, standardne devijacije te testirati normalnost distribucija frekvencija svake pojedinačne varijable, posebno za svaku skupinu sudionika u prometu s obzirom na iskustvo kažnjavanja te ih prikazati u navedenoj tablici. Definirane skupine sudionika u prometu s obzirom na iskustvo kažnjavanja jesu: 1 - ne, nisam nikada; 2 - jesam u zadnje dvije godine; 3 - jesam, prije 2-5 godina; 4 - jesam, prije više od 5 godina.

Tablica 3. Osnovni statistički pokazatelji i testiranje normalnosti distribucije frekvencija Kolmogorov-Smirnovljevim testom

\begin{tabular}{|c|c|c|c|c|c|c|c|}
\hline & & $\mathrm{N}$ & Arit. sr. & St. dev. & $\begin{array}{c}\text { Najmanji } \\
\text { rezultati }\end{array}$ & $\begin{array}{c}\text { Najveći } \\
\text { rezultati }\end{array}$ & $\begin{array}{c}\text { Kolmogorov- } \\
\text { Smirnovljev } \\
\text { test }\end{array}$ \\
\hline & & & & & & & - značajnost - \\
\hline
\end{tabular}


S. GLUŠČIĆ, Kažnjivo ponašanje sudionika u prometu utemeljeno na prethodnom...

\begin{tabular}{|c|c|c|c|c|c|c|c|}
\hline \multirow{5}{*}{$\begin{array}{l}\text { Q3. U kojoj mjeri } \\
\text { kršite prometne } \\
\text { propise koji se } \\
\text { odnose na vozače u } \\
\text { prometu? }\end{array}$} & 1 & 960 & 1,55 & 0,56 & 1 & 4 & \\
\hline & 2 & 161 & 1,92 & 0,53 & 1 & 4 & \\
\hline & 3 & 172 & 1,85 & 0,58 & 1 & 4 & 0,000 \\
\hline & 4 & 541 & 1,72 & 0,48 & 2 & 4 & \\
\hline & Total & 1834 & 1,76 & 0,54 & & & \\
\hline \multirow{5}{*}{$\begin{array}{l}\text { Q5. Molio/la bih } \\
\text { vas da procijenite } \\
\text { u kojoj mjeri kršite } \\
\text { prometne propise } \\
\text { koji se odnose na } \\
\text { pješake u prometu? }\end{array}$} & 1 & 1182 & 1,55 & 0,58 & 1 & 4 & \\
\hline & 2 & 161 & 1,70 & 0,65 & 1 & 4 & \\
\hline & 3 & 174 & 1,61 & 0,51 & 2 & 4 & 0,000 \\
\hline & 4 & 555 & 1,60 & 0,53 & 2 & 4 & \\
\hline & Total & 2072 & 1,62 & 0,57 & & & \\
\hline \multirow{5}{*}{$\begin{array}{l}\text { Q6.1. Prekoračenje } \\
\text { brzine do } 20 \mathrm{~km} / \mathrm{h} \\
\text { od dozvoljene. }\end{array}$} & 1 & 871 & 1,85 & 0,65 & 1 & 4 & \\
\hline & 2 & 160 & 2,19 & 0,68 & 1 & 4 & \\
\hline & 3 & 172 & 2,14 & 0,65 & 1 & 4 & 0,000 \\
\hline & 4 & 517 & 2,01 & 0,57 & 1 & 4 & \\
\hline & Total & 1720 & 2,05 & 0,64 & & & \\
\hline \multirow{5}{*}{$\begin{array}{l}\text { Q6.2. Prekoračenje } \\
\text { brzine od } 21 \text { do } 50 \\
\mathrm{~km} / \mathrm{h} \text { od dozvoljene. }\end{array}$} & 1 & 870 & 1,4 & 0,57 & 1 & 4 & \\
\hline & 2 & 159 & 1,84 & 0,63 & 1 & 4 & \\
\hline & 3 & 172 & 1,67 & 0,58 & 1 & 3 & 0,000 \\
\hline & 4 & 516 & 1,52 & 0,57 & 1 & 4 & \\
\hline & Total & 1717 & 1,61 & 0,59 & & & \\
\hline \multirow{5}{*}{$\begin{array}{l}\text { Q6.3. Prekoračenje } \\
\text { brzine više od } 50 \\
\mathrm{~km} / \mathrm{h} \text { od dozvoljene. }\end{array}$} & 1 & 876 & 1,13 & 0,39 & 1 & 4 & \\
\hline & 2 & 160 & 1,35 & 0,61 & 1 & 4 & \\
\hline & 3 & 172 & 1,23 & 0,5 & 1 & 4 & 0,000 \\
\hline & 4 & 518 & 1,17 & 0,41 & 1 & 4 & \\
\hline & Total & 1726 & 1,22 & 0,48 & & & \\
\hline \multirow{5}{*}{$\begin{array}{l}\text { Q6.4. Upravljanje } \\
\text { vozilom nakon } \\
\text { prethodne } \\
\text { konzumacije } \\
\text { alkohola. }\end{array}$} & 1 & 871 & 1,15 & 0,38 & 1 & 4 & \\
\hline & 2 & 160 & 1,47 & 0,61 & 1 & 4 & \\
\hline & 3 & 172 & 1,37 & 0,51 & 1 & 3 & 0,000 \\
\hline & 4 & 516 & 1,35 & 0,5 & 1 & 3 & \\
\hline & Total & 1719 & 1,34 & 0,5 & & & \\
\hline \multirow{5}{*}{$\begin{array}{l}\text { Q6.5. Pretjecanje } \\
\text { drugih vozila na } \\
\text { mjestu gdje to nije } \\
\text { dozvoljeno. }\end{array}$} & 1 & 871 & 1,28 & 0,49 & 1 & 4 & \\
\hline & 2 & 153 & 1,54 & 0,59 & 1 & 4 & \\
\hline & 3 & 171 & 1,51 & 0,53 & 1 & 3 & 0,000 \\
\hline & 4 & 518 & 1,35 & 0,5 & 1 & 3 & \\
\hline & Total & 1713 & 1,42 & 0,53 & & & \\
\hline \multirow{5}{*}{$\begin{array}{l}\text { Q6.6. Oduzimanje } \\
\text { prednosti prolaska } \\
\text { drugih vozila. }\end{array}$} & 1 & 868 & 1,23 & 0,45 & 1 & 4 & \\
\hline & 2 & 157 & 1,46 & 0,59 & 1 & 4 & \\
\hline & 3 & 171 & 1,24 & 0,45 & 1 & 3 & 0,000 \\
\hline & 4 & 514 & 1,24 & 0,44 & 1 & 3 & \\
\hline & Total & 1710 & 1,29 & 0,48 & & & \\
\hline \multirow{5}{*}{$\begin{array}{l}\text { Q6.7. Oduzimanje } \\
\text { prednosti } \\
\text { prolaska pješaka } \\
\text { (nezaustavljanje } \\
\text { na pješačkom } \\
\text { prijelazu). }\end{array}$} & 1 & 869 & 1,36 & 0,52 & 1 & 4 & \\
\hline & 2 & 160 & 1,46 & 0,56 & 1 & 3 & \\
\hline & 3 & 172 & 1,4 & 0,53 & 1 & 4 & 0,000 \\
\hline & 4 & 515 & 1,37 & 0,51 & 1 & 4 & \\
\hline & Total & 1716 & 1,40 & 0,53 & & & \\
\hline
\end{tabular}


S. GLUŠČIĆ, Kažnjivo ponašanje sudionika u prometu utemeljeno na prethodnom... Zbornik Pravnog fakulteta Sveučilišta u Rijeci, vol. 42, br. 3, 611-629 (2021)

\begin{tabular}{|c|c|c|c|c|c|c|c|}
\hline \multirow{5}{*}{$\begin{array}{l}\text { Q6.8. Nekorištenje } \\
\text { sigurnosnog pojasa } \\
\text { dok vozim. }\end{array}$} & 1 & 876 & 1,27 & 0,57 & 1 & 4 & \\
\hline & 2 & 160 & 1,47 & 0,76 & 1 & 4 & \\
\hline & 3 & 172 & 1,47 & 0,74 & 1 & 4 & 0,000 \\
\hline & 4 & 516 & 1,3 & 0,63 & 1 & 4 & \\
\hline & Total & 1724 & 1,38 & 0,68 & & & \\
\hline \multirow{5}{*}{$\begin{array}{l}\text { Q6.9. Vožnja } \\
\text { neregistriranog } \\
\text { vozila. }\end{array}$} & 1 & 875 & 1,02 & 0,18 & 1 & 4 & \\
\hline & 2 & 159 & 1,06 & 0,34 & 1 & 4 & \\
\hline & 3 & 172 & 1,03 & 0,21 & 1 & 3 & 0,000 \\
\hline & 4 & 518 & 1,02 & 0,15 & 1 & 3 & \\
\hline & Total & 1724 & 1,03 & 0,22 & & & \\
\hline \multirow{5}{*}{$\begin{array}{l}\text { Q6.10. Upravljanje } \\
\text { vozilom u vrijeme } \\
\text { zabrane zbog } \\
\text { propisanih kazni. }\end{array}$} & 1 & 867 & 1,02 & 0,16 & 1 & 4 & \\
\hline & 2 & 157 & 1,09 & 0,33 & 1 & 3 & \\
\hline & 3 & 172 & 1,05 & 0,29 & 1 & 4 & 0,000 \\
\hline & 4 & 510 & 1,02 & 0,15 & 1 & 3 & \\
\hline & Total & 1706 & 1,05 & 0,23 & & & \\
\hline \multirow{5}{*}{$\begin{array}{l}\text { Q6.11. Prolazak } \\
\text { na semaforu kroz } \\
\text { crveno svjetlo. }\end{array}$} & 1 & 875 & 1,08 & 0,31 & 1 & 4 & \\
\hline & 2 & 160 & 1,22 & 0,54 & 1 & 4 & \\
\hline & 3 & 171 & 1,08 & 0,29 & 1 & 3 & 0,000 \\
\hline & 4 & 512 & 1,09 & 0,3 & 1 & 3 & \\
\hline & Total & 1718 & 1,12 & 0,36 & & & \\
\hline \multirow{5}{*}{$\begin{array}{l}\text { Q6.12. } \\
\text { Nedozvoljeno } \\
\text { korištenje mobitela } \\
\text { za vrijeme } \\
\text { upravljanja vozilom. }\end{array}$} & 1 & 874 & 1,44 & 0,58 & 1 & 4 & \\
\hline & 2 & 160 & 1,73 & 0,68 & 1 & 4 & \\
\hline & 3 & 171 & 1,67 & 0,62 & 1 & 4 & 0,000 \\
\hline & 4 & 516 & 1,53 & 0,59 & 1 & 4 & \\
\hline & Total & 1721 & 1,59 & 0,62 & & & \\
\hline \multirow{5}{*}{$\begin{array}{l}\text { Q6.13. Nenošenje } \\
\text { zaštitne kacige kod } \\
\text { vožnje motocikla. }\end{array}$} & 1 & 490 & 1,15 & 0,49 & 1 & 4 & \\
\hline & 2 & 88 & 1,3 & 0,71 & 1 & 4 & \\
\hline & 3 & 104 & 1,2 & 0,51 & 1 & 3 & 0,000 \\
\hline & 4 & 516 & 1,2 & 0,5 & 1 & 4 & \\
\hline & Total & 1198 & 1,21 & 0,55 & & & \\
\hline \multirow{5}{*}{$\begin{array}{l}\text { Q6.14. } \\
\text { Neodržavanje } \\
\text { sigurnosnog } \\
\text { razmaka između } \\
\text { vozila. }\end{array}$} & 1 & 865 & 1,48 & 0,61 & 1 & 4 & \\
\hline & 2 & 160 & 1,84 & 0,59 & 1 & 4 & \\
\hline & 3 & 171 & 1,69 & 0,54 & 1 & 3 & 0,000 \\
\hline & 4 & 513 & 1,6 & 0,59 & 1 & 4 & \\
\hline & Total & 1709 & 1,65 & 0,58 & & & \\
\hline \multirow{5}{*}{$\begin{array}{l}\text { Q9.1. Nekorištenje } \\
\text { sigurnosnog } \\
\text { pojasa dok sjedim } \\
\text { na suvozačkom } \\
\text { sjedalu. }\end{array}$} & 1 & 1176 & 1,28 & 0,65 & 1 & 4 & \\
\hline & 2 & 160 & 1,48 & 0,78 & 1 & 4 & \\
\hline & 3 & 171 & 1,36 & 0,61 & 1 & 4 & 0,000 \\
\hline & 4 & 550 & 1,34 & 0,69 & 1 & 4 & \\
\hline & Total & 2057 & 1,37 & 0,68 & & & \\
\hline \multirow{5}{*}{$\begin{array}{l}\text { Q9.2. Nekorištenje } \\
\text { sigurnosnog pojasa } \\
\text { dok sjedim na } \\
\text { stražnjem sjedalu. }\end{array}$} & 1 & 1150 & 2,36 & 1,19 & 1 & 4 & \\
\hline & 2 & 158 & 2,67 & 1,12 & 1 & 4 & \\
\hline & 3 & 167 & 2,66 & 1,17 & 1 & 4 & 0,000 \\
\hline & 4 & 533 & 2,46 & 1,19 & 1 & 4 & \\
\hline & Total & 2008 & 2,54 & 1,17 & & & \\
\hline
\end{tabular}


S. GLUŠČIĆ, Kažnjivo ponašanje sudionika u prometu utemeljeno na prethodnom...

\begin{tabular}{|c|c|c|c|c|c|c|c|}
\hline \multirow{5}{*}{$\begin{array}{l}\text { Q9.3. Nevezivanje } \\
\text { djece sigurnosnim } \\
\text { pojasom u } \\
\text { automobilu ili } \\
\text { nekorištenje } \\
\text { propisanih sjedalica } \\
\text { za djecu. }\end{array}$} & 1 & 988 & 1,14 & 0,49 & 1 & 4 & \\
\hline & 2 & 144 & 1,32 & 0,75 & 1 & 4 & \\
\hline & 3 & 151 & 1,18 & 0,55 & 1 & 4 & 0,000 \\
\hline & 4 & 473 & 1,13 & 0,46 & 1 & 4 & \\
\hline & Total & 1756 & 1,19 & 0,56 & & & \\
\hline \multirow{5}{*}{$\begin{array}{l}\text { Q9.4. U funkciji } \\
\text { pješaka - prelaženje } \\
\text { kolnika na } \\
\text { neoznačenom } \\
\text { mjestu (gdje nema } \\
\text { pješačkog prijelaza). }\end{array}$} & 1 & 1177 & 2,01 & 0,69 & 1 & 4 & \\
\hline & 2 & 161 & 2,3 & 0,72 & 1 & 4 & \\
\hline & 3 & 172 & 2,22 & 0,62 & 1 & 4 & 0,000 \\
\hline & 4 & 553 & 2,09 & 0,6 & 1 & 4 & \\
\hline & Total & 2063 & 2,16 & 0,66 & & & \\
\hline \multirow{5}{*}{$\begin{array}{l}\text { Q9.5. U funkciji } \\
\text { pješaka - prelaženje } \\
\text { kolnika na } \\
\text { pješačkom prijelazu } \\
\text { kada je upaljeno } \\
\text { crveno svjetlo za } \\
\text { pješake. }\end{array}$} & 1 & 1176 & 1,5 & 0,66 & 1 & 4 & \\
\hline & 2 & 161 & 1,62 & 0,67 & 1 & 4 & \\
\hline & 3 & 172 & 1,5 & 0,59 & 1 & 4 & 0,000 \\
\hline & 4 & 551 & 1,45 & 0,59 & 1 & 4 & \\
\hline & Total & 2060 & 1,52 & 0,63 & & & \\
\hline
\end{tabular}

$\mathrm{Na}$ temelju osnovnih statističkih pokazatelja, aritmetičke sredine i standardne devijacije, može se zaključiti kako ispitanici češće krše prometne propise koji se odnose na vozače u prometu $(\mathrm{M}=1,76 ; \mathrm{SD}=0,54)$, negoli propise koji se odnose na pješake $(\mathrm{M}=1,62 ; \mathrm{SD}=0,57)$.

Od prekršaja koji se odnose na vozače, ispitanici najrjeđe čine prekršaj vožnje neregistriranog vozila $(M=1,03 ; \mathrm{SD}=0,22)$, zatim upravljanje vozilom tijekom zabrane zbog propisanih kazni $(\mathrm{M}=1,05 ; \mathrm{SD}=0,23)$, prolazak na semaforu kroz crveno svjetlo $(\mathrm{M}=1,12 ; \mathrm{SD}=0,36)$ te prekoračenje brzine više od $50 \mathrm{~km} / \mathrm{h}$ od dopuštene $(\mathrm{M}=1,22$; $\mathrm{SD}=0,48)$.

Kao vozači ispitanici, a što vrijedi i za građane Republike Hrvatske, s obzirom na to da je riječ o nacionalno reprezentativnom uzorku ispitanika, najčešće čine prekršaje prekoračenja brzine od $20 \mathrm{~km} / \mathrm{h}$ od dopuštene $(\mathrm{M}=2,05 ; \mathrm{SD}=0,64)$, neodržavanje sigurnosnog razmaka između vozila $(\mathrm{M}=1,65 ; \mathrm{SD}=0,58)$, prekoračenje brzine od 21 do $50 \mathrm{~km} / \mathrm{h}$ od dopuštene $(\mathrm{M}=1,61 ; \mathrm{SD}=0,59)$ te nedopušteno korištenje mobitela tijekom upravljanja vozilom $(\mathrm{M}=1,59 ; \mathrm{SD}=0,62)$.

S druge strane, kada su u svojstvu putnika u vozilu, ispitanici najčešće čine prekršaj nekorištenja sigurnosnog pojasa na stražnjem sjedalu u vozilu $(\mathrm{M}=2,44$; $\mathrm{SD}=1,17)$ i taj prekršaj čine puno češće negoli kada su putnici na suvozačevu sjedalu.

Kada su u funkciji pješaka, ispitanici češće prelaze kolnik na neoznačenu mjestu (gdje nema pješačkog prijelaza) $(\mathrm{M}=2,16$; $\mathrm{SD}=0,66)$, negoli prekršaj - prelaženje kolnika na pješačkom prijelazu kada je upaljeno crveno svjetlo za pješake $(M=1,52$; $\mathrm{SD}=0,63)$.

Iz tablice 1. proizlazi da distribucije frekvencija ni jedne varijable nisu normalne jer su značajnosti manje od $0,05 \%(\mathrm{p}=0,000)$. Budući da su varijable kod svake skupine sudionika u prometu s obzirom na iskustvo kažnjavanja nenormalno distribuirane za ispitivanje razlika između tih skupina sudionika u prometu, korišten je Kruskal-Wallisov test čiji su rezultati prikazani u tablici 4. 
Tablica 4. Razlika između skupina sudionika u prometu, s obzirom na iskustvo kažnjavanja, izračunate korištenjem Kruskal-Wallisova testa

\begin{tabular}{|c|c|c|c|c|c|}
\hline & & $\mathrm{N}$ & $\begin{array}{l}\text { Srednji } \\
\text { rangovi }\end{array}$ & Hi-kvadrat & $\mathrm{p}$ \\
\hline \multirow{5}{*}{$\begin{array}{l}\text { Q3. U kojoj mjeri kršite prometne } \\
\text { propise koji se odnose na vozače u } \\
\text { prometu? }\end{array}$} & 1 & 957 & 818,97 & 115,359 & 0,000 \\
\hline & 2 & 161 & 1126,64 & & \\
\hline & 3 & 175 & 1082,61 & & \\
\hline & 4 & 545 & 982,46 & & \\
\hline & Total & 1838 & & & \\
\hline \multirow{5}{*}{$\begin{array}{l}\text { Q5. Procijenite u kojoj mjeri kršite } \\
\text { prometne propise koji se odnose na } \\
\text { pješake u prometu. }\end{array}$} & 1 & 1175 & 1004,23 & & \\
\hline & 2 & 161 & 1132,52 & & \\
\hline & 3 & 177 & 1077,97 & 12,419 & 0,006 \\
\hline & 4 & 559 & 1063,55 & & \\
\hline & Total & 2072 & & & \\
\hline \multirow{5}{*}{$\begin{array}{l}\text { Q6.1. Prekoračenje brzine do } 20 \mathrm{~km} / \mathrm{h} \\
\text { od dozvoljene. }\end{array}$} & 1 & 868 & 785,04 & & \\
\hline & 2 & 160 & 1010,85 & & \\
\hline & 3 & 175 & 981,48 & 67,600 & 0,000 \\
\hline & 4 & 521 & 906,03 & & \\
\hline & Total & 1724 & & & \\
\hline \multirow{5}{*}{$\begin{array}{l}\text { Q6.2. Prekoračenje brzine od } 21 \text { do } 50 \\
\mathrm{~km} / \mathrm{h} \text { od dozvoljene. }\end{array}$} & 1 & 867 & 778,14 & & \\
\hline & 2 & 159 & 1105,89 & & \\
\hline & 3 & 174 & 989,43 & 97,638 & 0,000 \\
\hline & 4 & 520 & 879,65 & & \\
\hline & Total & 1720 & & & \\
\hline \multirow{5}{*}{$\begin{array}{l}\text { Q6.3. Prekoračenje brzine više od } 50 \\
\mathrm{~km} / \mathrm{h} \text { od dozvoljene. }\end{array}$} & 1 & 873 & 835,78 & & \\
\hline & 2 & 160 & 979,44 & & \\
\hline & 3 & 174 & 907,04 & 32,456 & 0,000 \\
\hline & 4 & 522 & 864,78 & & \\
\hline & Total & 1729 & & & \\
\hline \multirow{5}{*}{$\begin{array}{l}\text { Q6.4. Upravljanje vozilom nakon } \\
\text { prethodne konzumacije alkohola. }\end{array}$} & 1 & 868 & 771,47 & & \\
\hline & 2 & 160 & 1011,87 & & \\
\hline & 3 & 174 & 955,15 & 106,842 & 0,000 \\
\hline & 4 & 521 & 935,70 & & \\
\hline & Total & 1723 & & & \\
\hline \multirow{5}{*}{$\begin{array}{l}\text { Q6.5. Pretjecanje drugih vozila na } \\
\text { mjestu gdje to nije dozvoljeno. }\end{array}$} & 1 & 868 & 802,03 & & \\
\hline & 2 & 158 & 1013,47 & & \\
\hline & 3 & 173 & 999,84 & 60,677 & 0,000 \\
\hline & 4 & 522 & 866,89 & & \\
\hline & Total & 1721 & & & \\
\hline \multirow{5}{*}{$\begin{array}{l}\text { Q6.6. Oduzimanje prednosti prolaska } \\
\text { drugih vozila. }\end{array}$} & 1 & 865 & 835,08 & & \\
\hline & 2 & 157 & 1015,81 & & \\
\hline & 3 & 173 & 840,70 & 32,592 & 0,000 \\
\hline & 4 & 518 & 850,92 & & \\
\hline & Total & 1713 & & & \\
\hline
\end{tabular}


S. GLUŠČIĆ, Kažnjivo ponašanje sudionika u prometu utemeljeno na prethodnom...

\begin{tabular}{|c|c|c|c|c|c|}
\hline \multirow{5}{*}{$\begin{array}{l}\text { Q6.7. Oduzimanje prednosti prolaska } \\
\text { pješaka (nezaustavljanje na pješačkom } \\
\text { prijelazu). }\end{array}$} & 1 & 866 & 846,66 & & \\
\hline & 2 & 160 & 926,09 & & \\
\hline & 3 & 174 & 884,05 & 5,610 & 0,132 \\
\hline & 4 & 520 & 855,50 & & \\
\hline & Total & 1720 & & & \\
\hline \multirow{5}{*}{$\begin{array}{l}\text { Q6.8. Nekorištenje sigurnosnog pojasa } \\
\text { dok vozim. }\end{array}$} & 1 & 873 & 829,13 & & \\
\hline & 2 & 160 & 939,34 & 24,643 & 0,000 \\
\hline & 3 & 174 & 957,62 & & \\
\hline & 4 & 521 & 869,69 & & \\
\hline & Total & 1728 & & & \\
\hline \multirow[t]{5}{*}{ Q6.9. Vožnja neregistriranog vozila. } & 1 & 872 & 862,37 & & \\
\hline & 2 & 159 & 875,88 & & \\
\hline & 3 & 175 & 873,17 & 2,712 & 0,438 \\
\hline & 4 & 523 & 863,34 & & \\
\hline & Total & 1729 & & & \\
\hline \multirow{5}{*}{$\begin{array}{l}\text { Q6.10. Upravljanje vozilom za vrijeme } \\
\text { zabrane zbog propisanih kazni. }\end{array}$} & 1 & 864 & 846,89 & & \\
\hline & 2 & 157 & 901,31 & & \\
\hline & 3 & 174 & 870,38 & 28,425 & 0,000 \\
\hline & 4 & 514 & 849,29 & & \\
\hline & Total & 1709 & & & \\
\hline \multirow{5}{*}{$\begin{array}{l}\text { Q6.11. Prolazak na semaforu kroz } \\
\text { crveno svjetlo. }\end{array}$} & 1 & 872 & 847,84 & & \\
\hline & 2 & 160 & 939,45 & 19,837 & 0,000 \\
\hline & 3 & 174 & 851,79 & & \\
\hline & 4 & 516 & 863,86 & & \\
\hline & Total & 1722 & & & \\
\hline \multirow{5}{*}{$\begin{array}{l}\text { Q6.12. Nedozvoljeno korištenje } \\
\text { mobitela za vrijeme upravljanja } \\
\text { vozilom. }\end{array}$} & 1 & 871 & 805,21 & & \\
\hline & 2 & 160 & 1006,76 & & \\
\hline & 3 & 174 & 979,54 & 45,143 & 0,000 \\
\hline & 4 & 521 & 878,21 & & \\
\hline & Total & 1726 & & & \\
\hline \multirow{5}{*}{$\begin{array}{l}\text { Q6.13. Nenošenje zaštitne kacige kod } \\
\text { vožnje motocikla. }\end{array}$} & 1 & 489 & 459,80 & & \\
\hline & 2 & 88 & 495,53 & & \\
\hline & 3 & 106 & 479,09 & 5,604 & 0,133 \\
\hline & 4 & 258 & 480,53 & & \\
\hline & Total & 941 & & & \\
\hline \multirow{5}{*}{$\begin{array}{l}\text { Q6.14. Neodržavanje sigurnosnog } \\
\text { razmaka između vozila. }\end{array}$} & 1 & 862 & 780,15 & & \\
\hline & 2 & 160 & 1060,10 & 74,008 & 0,000 \\
\hline & 3 & 174 & 963,49 & & \\
\hline & 4 & 517 & 886,44 & & \\
\hline & Total & 1713 & & & \\
\hline \multirow{5}{*}{$\begin{array}{l}\text { Q9.1. Nekorištenje sigurnosnog pojasa } \\
\text { dok sjedim na suvozačkom sjedalu. }\end{array}$} & 1 & 1169 & 993,51 & & \\
\hline & 2 & 160 & 1150,38 & & \\
\hline & 3 & 174 & 1099,86 & 25,831 & 0,000 \\
\hline & 4 & 554 & 1046,57 & & \\
\hline & Total & 2057 & & & \\
\hline
\end{tabular}




\begin{tabular}{|l|c|c|c|c|c|}
\hline Q9.2. Nekorištenje sigurnosnog pojasa & 1 & 1144 & 967,91 & & \\
\cline { 2 - 7 } dok sjedim na stražnjem sjedalu. & 2 & 158 & 1119,47 & & \\
\cline { 2 - 7 } & 3 & 170 & 1107,03 & 17,580 & 0,001 \\
\cline { 2 - 7 } & 4 & 537 & 1008,03 & & \\
\cline { 2 - 7 } & Total & 2009 & & & \\
\hline \multirow{4}{*}{$\begin{array}{l}\text { Q9.3. Nevezivanje djece sigurnosnim } \\
\text { pojasom u automobilu ili nekorištenje } \\
\text { propisanih sjedalica za djecu. }\end{array}$} & 1 & 984 & 868,81 & & \\
\cline { 2 - 7 } & 3 & 144 & 965,19 & 16,273 & 0,001 \\
\cline { 2 - 7 } & 4 & 477 & 879,89 & & \\
\cline { 2 - 7 } & Total & 1759 & & & \\
\hline \multirow{4}{*}{$\begin{array}{l}\text { Q9.4. U funkciji pješaka - prelaženje } \\
\text { kolnika na neoznačenome mjestu (gdje }\end{array}$} & 1 & 1170 & 978,03 & & \\
\cline { 2 - 7 } nema pješačkog prijelaza). & 2 & 161 & 1204,62 & & \\
\cline { 2 - 7 } & 3 & 175 & 1152,98 & 42,061 & 0,000 \\
\cline { 2 - 7 } & 4 & 557 & 1057,47 & & \\
\cline { 2 - 6 } & Total & 2063 & & & \\
\hline \multirow{4}{*}{$\begin{array}{l}\text { Q9.5. U funkciji pješaka - prelaženje } \\
\text { kolnika na pješačkom prijelazu kada je }\end{array}$} & 1 & 1169 & 1026,57 & & \\
\cline { 2 - 7 } upaljeno crveno svjetlo za pješake. & 2 & 161 & 1136,22 & & \\
\cline { 2 - 6 } & 3 & 175 & 1047,46 & 8,507 & 0,037 \\
\cline { 2 - 6 } & 4 & 555 & 1002,76 & & \\
\cline { 2 - 6 } & Total & 2060 & & & \\
\hline
\end{tabular}

Rezultati Kruskal-Wallisova testa na varijabli Q3 (u kojoj mjeri kršite prometne propise koji se odnose na vozače u prometu) prikazani u tablici 4. pokazuju kako postoji statistički značajna razlika između ispitanika koji nisu kažnjavani (1) i onih koji su kažnjavani (2, 3 i 4), bez obzira na protek vremena od iskustva kažnjavanja $\left(\mathrm{hi}^{2}=115,359, \mathrm{p}<0,000\right)$. Prema veličini srednjih rangova, kažnjavani ispitanici (bez obzira na to u kojoj su skupini s obzirom na razdoblje kažnjavanja) češće krše prometne propise koji se odnose na vozače u prometu. Statistički značajne razlike potvrđene su između nekažnjavanih ispitanika i svih parova grupa kažnjavanih ispitanika, bez obzira na razdoblje kažnjavanja.

U odnosu na kažnjivo ponašanje, odnosno kršenje prometnih propisa koji se odnose na pješake u prometu na varijabli Q5 (u kojoj se mjeri krše prometni propisi koji se odnose na pješake u prometu), rezultati Kruskal-Wallisova testa ponovno pokazuju da je utvrđena statistički značajna razlika između ispitanika koji nisu kažnjavani zbog kršenja prometnih propisa kao pješaci, vozači automobila, motocikala, bicikala i dr. i onih koji to jesu $\left(\mathrm{hi}^{2}=12,419 ; \mathrm{p}=0,006\right)$. Srednji rangovi ponovno potvrđuju da kažnjavani ispitanici (bez obzira na vrijeme kažnjavanja) više krše propise koji se odnose na pješake u prometu. Međutim, kada usporedimo parove ispitanika, razlika postoji samo među onim ispitanicima koji nisu kažnjavani i ispitanicima koji su kažnjavani u zadnje dvije godine. Kažnjavanje nakon kojeg je proteklo više od dvije godine ne čini razliku u odnosu na ponašanje pješaka u prometu.

Već na temelju testiranja dviju varijabli koje se odnose na opće kršenje prometnih propisa, bez obzira na svojstvo sudjelovanja u prometu, može se zaključiti kako kazne ne ostvaruju učinak odvraćanja počinitelja od ponavljanja prekršaja u prometu (specijalne prevencije) jer i nakon kažnjavanja, prema podatcima dobivenim na 
temelju samoiskaza ispitanika, kažnjene osobe češće čine prekršaje od nekažnjavanih sudionika u prometu.

S obzirom na prethodne rezultate važno je testirati stanje u odnosu na neke najčešće prekršaje u prometu.

Iz tablice 4. proizlazi da su statistički značajne razlike između ispitanika s obzirom na njihovo iskustvo kažnjavanja dobivene na varijabli Q6.1 (Prekoračenje brzine do $20 \mathrm{~km} / \mathrm{h}$ od dozvoljene) jer je $\mathrm{hi}^{2}=67,600$, a $\mathrm{p}<0,000$. Na temelju srednjih rangova može se zaključiti da ovaj prekršaj češće čine vozači koji su kažnjavani, bez obzira na to kada, a posebno oni vozači koji su kažnjeni unutar dvije godine. Ovaj prekršaj najrjeđe čine oni vozači koji nisu kažnjavani.

Slične rezultate pokazale su i varijable Q6.2. (Prekoračenje brzine od 21 do 50 $\mathrm{km} / \mathrm{h}$ od dopuštene), Q6.3. (Prekoračenje brzine više od $50 \mathrm{~km} / \mathrm{h}$ od dopuštene),Q6.4. (Upravljanje vozilom nakon prethodne konzumacije alkohola), Q6.5. (Pretjecanje drugih vozila na mjestu gdje to nije dopušteno), Q6.12. (Nedopušteno korištenje mobitela tijekom upravljanja vozilom), Q6.14. (Neodržavanje sigurnosnog razmaka između vozila). Kod navedenih varijabli, na temelju srednjih rangova može se zaključiti da ove prekršaje češće čine vozači koji su kažnjavani, bez obzira na to kada, a posebno oni vozači koji su kažnjeni unutar dvije godine. Ove prekršaje najrjeđe čine oni vozači koji nisu kažnjavani.

Kod varijable Q6.6. (Oduzimanje prednosti prolaska drugih vozila) na temelju srednjih rangova može se zaključiti, da ovaj prekršaj također, a češće čine vozači koji su kažnjavani; od kojih takav prekršaj najmanje čine oni koji su kažnjeni prije dvije do pet godina. Ovaj prekršaj najrjeđe čine vozači koji nisu ranije kažnjavani.

$\mathrm{Na}$ temelju srednjih rangova kod varijable Q6.8. (Nekorištenje sigurnosnog pojasa dok vozim), Q6.10. (Upravljanje vozilom za vrijeme zabrane zbog propisanih kazni) i Q6.11. (Prolazak na semaforu kroz crveno svjetlo) - može se zaključiti da svi vozači koji su prije kažnjavani podjednako često čine navedene prekršaje, a najrjeđe ih čine oni vozači koji nisu kažnjavani.

Kod svih ostalih varijabli Q6.7., Q6.9. i Q6.13. nisu dobivene statistički značajne razlike jer su značajnosti veće od dopuštenih 5 \% (Asymp. Sig. (2-tailed) - značajnost $\mathrm{p}>5 \%$ ).

S druge strane, kod varijabli koje se odnose na prekršaje vezane za putnike u vozilu Q9.1. (Nekorištenje sigurnosnog pojasa dok sjedim na suvozačkom sjedalu), Q9.2. (Nekorištenje sigurnosnog pojasa dok sjedim na stražnjem sjedalu), Q9.3. (Nevezivanje djece sigurnosnim pojasom u automobilu ili nekorištenje propisanih sjedalica za djecu), na temelju srednjih rangova može se zaključiti da ove prekršaje češće čine ispitanici koji su kažnjavani, bez obzira na to kada, a posebno oni ispitanici koji su kažnjeni unutar dvije godine. Ove prekršaje najrjeđe čine oni ispitanici koji nisu kažnjavani. 
Tablica 5. Prekršaji koji najčešće prouzroče prometne nesreće

\begin{tabular}{|c|c|c|c|c|c|c|c|c|c|c|c|}
\hline Prekršaji & \multicolumn{2}{|c|}{$\begin{array}{c}\text { Nepropisna } \\
\text { brzina (u } \\
\text { naseljenom mjestu } \\
\text { i izvan naseljenog } \\
\text { mjesta) }\end{array}$} & \multicolumn{2}{|c|}{$\begin{array}{l}\text { Upravljanje } \\
\text { vozilom pod } \\
\text { utjecajem } \\
\text { alkohola }\end{array}$} & \multicolumn{2}{|c|}{$\begin{array}{l}\text { Nekorištenje } \\
\text { sigurnosnog } \\
\text { pojasa i/ili } \\
\text { sjedalice za } \\
\text { djecu }\end{array}$} & \multicolumn{2}{|c|}{$\begin{array}{c}\text { Nepropisna } \\
\text { uporaba } \\
\text { mobitela } \\
\text { tijekom vožnje }\end{array}$} & \multicolumn{2}{|c|}{$\begin{array}{c}\text { Ukupan broj } \\
\text { prekršaja koji su } \\
\text { najčešći uzroci } \\
\text { prometnih } \\
\text { nesreća } \\
\text { (kolone od } 1 \text { do 4) } \\
\text { u aps. iznosu i \% u } \\
\text { odnosu na ukupan } \\
\text { broj evidentiranih } \\
\text { prekršaja }\end{array}$} & $\begin{array}{c}\text { Ukupan } \\
\text { broj } \\
\text { evidentiranih } \\
\text { prekršaja } \\
\text { aps. } \\
100 \%\end{array}$ \\
\hline \multicolumn{12}{|l|}{ Godina } \\
\hline 2011. & 224.883 & $29,21 \%$ & 39.227 & $5,09 \%$ & 82.004 & $10,65 \%$ & 22.137 & $2.87 \%$ & 368.251 & $47,84 \%$ & 769.721 \\
\hline 2012. & 218.468 & $29,87 \%$ & 38.193 & $5,22 \%$ & 76.385 & $10,44 \%$ & 24.504 & $3,48 \%$ & 357.550 & $48,89 \%$ & 731.239 \\
\hline 2013. & 218.552 & $29,83 \%$ & 39.402 & $5,37 \%$ & 81.669 & $11,14 \%$ & 31.772 & $4,33 \%$ & 371.395 & $50,7 \%$ & 732.475 \\
\hline 2014. & 264.237 & $33,08 \%$ & 39.960 & $5 \%$ & 91.467 & $11,45 \%$ & 40.425 & $5,06 \%$ & 436.089 & $54,6 \%$ & 798.596 \\
\hline 2015. & 279.813 & $33,79 \%$ & 41.071 & $4,96 \%$ & 96.403 & $11,64 \%$ & 38.988 & $4,71 \%$ & 456.275 & $55,13 \%$ & 827.628 \\
\hline 2016. & 323.564 & $39,14 \%$ & 44.099 & $5,33 \%$ & 87.613 & $10,59 \%$ & 36.667 & $4,43 \%$ & 491.943 & $59,51 \%$ & 826.576 \\
\hline 2017. & 296.666 & $39,4 \%$ & 37.940 & $5,03 \%$ & 80.560 & $10,7 \%$ & 37.388 & $4,96 \%$ & 452.554 & $60,11 \%$ & 752.785 \\
\hline 2018. & 283.044 & $39,19 \%$ & 39.250 & $5,43 \%$ & 85.464 & $11,83 \%$ & 40.971 & $5,67 \%$ & 448.729 & $62,14 \%$ & 722.095 \\
\hline 2019. & 285.374 & $39,94 \%$ & 32.397 & $4,53 \%$ & 70.706 & $9,89 \%$ & 43.240 & $6,05 \%$ & 431.717 & $60,43 \%$ & 714.399 \\
\hline 2020. & 296.499 & $42,56 \%$ & 30.797 & $4,42 \%$ & 72.704 & $10,43 \%$ & 45.066 & $6,46 \%$ & 445.066 & $63,89 \%$ & 696.540 \\
\hline
\end{tabular}

Kao najčešći uzroci prometnih nesreća koji su povezani s kršenjem prometnih pravila utvrđuju se sljedeći: nepoštovanje propisane brzine kretanja; vožnja pod utjecajem alkohola; nekorištenje sigurnosnih pojaseva i autosjedalica za djecu i nedopuštena uporaba mobitela tijekom upravljanja motornim vozilom. ${ }^{14}$

U tablici 5. prikazani su podatci o kretanju navedenih prekršaja prema Biltenu sigurnosti cestovnog prometa koje objavljuje Ministarstvo unutarnjih poslova Republike Hrvatske. ${ }^{15}$ Prema prikupljenim podatcima vidljiv je kontinuirani rast (osim za 2019. godinu) navedenih prekršaja u ukupnom broju što dovodi do zaključka da se i policija u svojem radu više usmjerava na ove prekršaje jer oni dovode do težih posljedica. Prema podatcima za pojedine prekršaje iz prikazane kategorije vidljiva je tendencija pada broja prekršaja koji se odnose na konzumaciju alkohola, relativan pad prekršaja koji se odnose na korištenje sigurnosnoga pojasa i sjedalice za djecu te rast prekršaja koji se odnose na nedopuštenu uporabu mobitela tijekom vožnje. ${ }^{16}$

\section{ZAKLJUČAK}

U radu se prikazuju i analiziraju podatci koji se odnose na provedeno istraživanje u cilju ispitivanja postoji li razlika u kažnjivom ponašanju sudionika u prometu (vozača, putnika u vozilu i pješaka) s obzirom na njihovo prethodno iskustvo kažnjavanja. Kad se podatci pribavljeni istraživanjem usporede s podatcima o evidentiranim prekršajima - zaključuje se kako iskustvo prethodnoga kažnjavanja utječe na određena

14 Izvješće o provedbi projekta Analiza kritičnih čimbenika nastanka prometnih nesreća (Zagreb: Fakultet prometnih znanosti, zavod za prometno planiranje, 2020.), voditelj projekta: dr. sc. Marko Ševrović; vidi i podatke dostupne na: https://mup.gov.hr.

15 Bilten sigurnosti cestovnog prometa, dostupno na: mup.gov.hr/pristup-informacijama

16 Podatci dostupni na: https://mup.gov.hr. 
ponašanja u prometu. Prema iskazima ispitanika utjecaj kažnjavanja vidljiv je kod vozača, a odnosi se na počinjenje prekršaja tako da se najrjeđe čini prekršaj vožnje neregistriranog vozila, upravljanje vozilom tijekom zabrane zbog propisanih kazni, prolazak na semaforu kroz crveno svjetlo te prekoračenje brzine više od $50 \mathrm{~km} / \mathrm{h}$ od dopuštene. Istodobno se najčešće čine prekršaji prekoračenje brzine od $20 \mathrm{~km} / \mathrm{h}$ do 50 $\mathrm{km} / \mathrm{h}$ od dopuštene, neodržavanje sigurnosnoga razmaka između vozila te nedopušteno korištenje mobitela tijekom upravljanja vozilom. Kad se ovi podatci usporede s registriranim prekršajima - vidljiva je njihova podudarnost jer se i kod prekoračenja brzine kretanja kao i kod nedopuštenoga korištenja mobitela vidi kontinuirani rast zabilježenih prekršaja i njihov znatan udjel u ukupnom broju prekršaja.

S druge strane, kada su u svojstvu putnika u vozilu, ispitanici najčešće čine prekršaj nekorištenja sigurnosnoga pojasa na stražnjem sjedalu u vozilu i taj prekršaj čine puno češće nego kada su putnici na suvozačevu sjedalu. Kad vozači u prometu sudjeluju kao pješaci, ispitanici iskazuju kako često čine prekršaj prelaska kolnika na neoznačenome mjestu (gdje nema pješačkog prijelaza).

Rezultati pokazuju kako postoji statistički značajna razlika između ispitanika koji nisu kažnjavani i onih koji su kažnjavani, bez obzira na protek vremena od iskustva kažnjavanja. Iz dobivenih rezultata proizlazi da su statistički značajne razlike između ispitanika s obzirom na njihovo iskustvo kažnjavanja dobivene na varijabli kod prekršaja prekoračenje brzine do $20 \mathrm{~km} / \mathrm{h}$ od dopuštene. Na temelju dobivenih rezultata može se zaključiti da ovaj prekršaj češće čine vozači koji su kažnjavani, bez obzira na to kada; a posebno oni vozači koji su kažnjeni unutar dvije godine. Posebno je zanimljivo da ovaj prekršaj najrjeđe čine oni vozači koji nisu kažnjavani. Slične rezultate pokazale su i varijable prekoračenje brzine od 21 do $50 \mathrm{~km} / \mathrm{h}$ od dopuštene, prekoračenje brzine više od $50 \mathrm{~km} / \mathrm{h}$ od dopuštene i upravljanje vozilom nakon prethodne konzumacije alkohola, pretjecanje drugih vozila na mjestu gdje to nije dopušteno, nedopušteno korištenje mobitela tijekom upravljanja vozilom te neodržavanje sigurnosnoga razmaka između vozila. Može se istaknuti kako kažnjavanje počinitelja ne utječe kod svih ponašanja na otklanjanje budućih kažnjivih ponašanja iste vrste.

Zaključno, nije dokazano da je kažnjavanjem ostvarena svrha specijalne prevencije na način da kažnjavanje sudionika u prometu odvraća od budućega kažnjivog ponašanja. To potvrđuje tezu kako se politika sigurnosti prometa na cestama, prema ovom istraživanju, ne treba temeljiti na instrumentalnoj teoriji koja govori kako će ljudi poštovati pravne propise jer se boje kažnjavanja. Kažnjivo ponašanje sudionika u prometu stoga nije uvjetovano kaznom već vrlo vjerojatno uvjerenjem pojedinca o opasnosti pojedinih radnji u prometu te osobnim stavom o poželjnosti poštovanja prometnih propisa. Valja napomenuti kako je prediktore ponašanja sudionika $u$ prometu potrebno još dublje istražiti te da rezultati ovoga istraživanja pružaju dobar poticaj za takva istraživanja. 


\section{LITERATURA}

1. Bojanić, Igor i Marin Mrčela. „Svrha kažnjavanja u kontekstu šeste novele Kaznenog zakona“. Hrvatski ljetopis za kazneno pravo i praksu 13, br. 2 (2006): 431-449.

2. Centar za policijska istraživanja. Utjecaj raznih čimbenika na sigurnost cestovnog prometa - Istraživanje javnog mnijenja o stanju sigurnosti, ponašanju te navikama sudionika u cestovnom prometu. Pristup 4. lipnja 2021., https://cpi.gov.hr/UserDocsImages/ publikacije/2020/promet/Izvjesce_promet_final_2020.pdf

3. Dacić, Suada i Sabira Salihović. „Čovjek kao čimbenik pouzdanosti dinamičkog sustava vozač - vozilo - okolina“. Sigurnost 53, br. 2 (2011): 331-340.

4. Garačić, Ana. Kazneni zakon u sudskoj praksi. Zagreb: Organizator, 2006.

5. Horvatić, Željko i Leo Cvitanović. Politika suzbijanja kriminaliteta. Zagreb: Ministarstvo unutarnjih poslova, 1999.

6. Hrvatski auto klub. Izvješće o provedenom projektu (2015): istraživanje učestalosti korištenja sigurnosnog pojasa u osobnim automobilima i zaštitnih kaciga na motociklima $i$ mopedima, Fakultet prometnih znanosti, Zavod za prometno planiranje, voditelj projekta: dr. sc. Marko Ševrović. Pristup 4. lipnja 2021., https://www.hak.hr/vijest/571/ projekt-klik-11-2015

7. Maloić, Snježana. „Suvremeni pristupi kažnjavanju kao determinante kvalitete života u obitelji, susjedstvu i zajednici - nove perspektive suzbijanja kriminala“. Kriminologija $i$ socijalna integracija 21, br. 2 (2013): 31-44.

8. Ministarstvo unutarnjih poslova Republike Hrvatske. Izvješća o stanju sigurnosti cestovnog prometa. Pristup 4. lipnja 2021., https://mup.gov.hr/pristupinformacijama-16/statistika-228/statistika-mup-a-i-bilteni-o-sigurnosti-cestovnogprometa/283233Hrvatske.

9. Novoselec, Petar. Opći dio kaznenog prava. Zagreb: Pravni fakultet Sveučilišta u Zagrebu, 2009.

10. Oset, Snježana. „Prekršajnopravne sankcije de lege lata i de lege ferenda“. Hrvatski ljetopis za kazneno pravo i praksu 12, br. 2 (2005): 503-540.

11. Rotim, Franko. Elementi sigurnosti cestovnog prometa. Zagreb: Znanstveni savjet za promet JAZU, 1990.

12. Tokić, Andrea, Diana Dragaš i Ljiljana Gregov. Stilovi vožnje i rizik od prometnih prekršaja i nezgoda, Suvremena psihologija 19, br. 2 (2016): 195-204.

13. Tyler, R. Tom. Why Poople obey the Law. New Heven and London: Yale University Press, 1990.

14. Uzelac, Alen. Istina u sudskom postupku. Zagreb: Pravni fakultet u Zagrebu, 1997.

15. Veić, Petar i Stjepan Gluščić. Prekršajno pravo, Opći dio. 2. izmijenjeno i dopunjeno izd. Zagreb: Narodne novine, 2013.

16. Vukosav, Joško i Predrag Zarevski. Metodologija istraživanja sigurnosnih pojava. Zagreb: Ministarstvo unutarnjih poslova Republike Hrvatske, 2014.

17. Vukosav, Joško i Predrag Zarevski. Metodologija znanstvenih istraživanja. Zagreb: Ministarstvo unutarnjih poslova Republike Hrvatske, 2011.

18. World Health Organisation. Global status report on road safety. Ženeva, Švicarska: Management of Noncommunicable Diseases, Disability, Violence and Injury Prevention (NVI), 2015., pristup 13. rujna 2021., https://issuu.com/globalncap/docs/global_status_ report_on_road_safety

19. Prekršajni zakon, Narodne novine, br. 107/07., 39/13., 157/13., 110/15., 70/17., 118/18.

20. Zakon o sigurnosti prometa na cestama, Narodne novine, br. 67/08., 48/10., 74/11., 80/13., 158/13., 92/14., 64/15., 108/17., 70/19., 42/20. 


\title{
Stjepan Gluščić*
}

\author{
Summary
}

\section{CRIMINAL BEHAVIOR OF TRAFFIC PARTICIPANTS BASED ON PREVIOUS EXPERIENCE OF PUNISHMENT}

The paper deals with behaviors that most often lead to serious traffic accidents. These behaviors are categorized as misdemeanors. In addition to the analysis of these violations in the last ten years, the research part of the paper analyzes the data collected by the public opinion poll (2072 respondents) on the state of traffic safety, behavior and habits of the participants themselves. The aim of this analysis and research was to determine whether there is a difference in the criminal behavior of road users with regard to previous experience in punishment and based on the results to determine measures to strengthen road safety and reduce traffic accidents (criminal offenses and misdemeanors).

Keywords: offenses; safety; road traffic; punishment.

* Stjepan Gluščić, Ph.D., Assistant Professor, Police College in Zagreb; sgluscic@fkz.hr. ORCID: https://orcid.org/0000-0002-2243-2694. 
